\title{
OREGANO ESSENTIAL OIL AS ANTIMICROBIAL AGENT IN BROILERS DIET
}

\author{
Surama Freitas Zanini ${ }^{1}$, Dyeime Ribeiro Sousa ${ }^{1}$, Maria Regina Alves Rodrigues², \\ Maria Aparecida Silva ${ }^{3}$, Marcos Santos Zanini', Geraldo Luiz Colnago ${ }^{4}$ \\ 1 UFES \\ 2 UFPEL \\ 3 UENF \\ ${ }^{4}$ UFF \\ Correspondência: Dyeime Ribeiro Sousa: dyeimester@hotmail.com
}

\begin{abstract}
The study was carried out to evaluate the dietary supplementation of oregano essential oil on performance and antimicrobial activity of broilers. A total of 250 day-old male were distributed in a completely randomized design divided into five groups with five replicates, each given a basal diet with avilamycin plus salinomycin (positive control) or a basal diet without added avilamycin and salinomycin (negative control) or basal diet with only added avilamycin or a basal diet supplemented with $0.5 \mathrm{~g}$ of oregano oil $/ \mathrm{kg}$ diet, or $1.0 \mathrm{~g}$ of oregano oil/kg diet. It was observed lower frequency of gram-positive bacteria in the ileum of the negative control group compared to chickens treated with the positive control group or supplemented with oregano oil $(p<0.01)$. Lactobacillus spp. had a higher growth in the positive control group or supplemented with $1 \mathrm{~g}$ of oregano oil/kg diet $(p<0.05)$. However, the frequency of Lactobacillus spp. in broilers supplemented with $0.5 \mathrm{~g}$ of oregano oil $/ \mathrm{kg}$ diet was lower than those supplemented with $1 \mathrm{~g}$ of oregano oil/ $\mathrm{kg}$ diet $(\mathrm{p}<0.05)$ as well, as it did not differ from the negative control group $(p>0.05)$. It was observed that the use of $1.0 \mathrm{~g}$ of oregano oil/kg diet resulted in the lower relative intestine weight $(p<0.05)$ which did not differ significantly from the positive control group $(p>$ 0.05). The results showed that the dietary oregano oil exerted growth-promoting effect on broilers at $1.0 \mathrm{~g}$ of oregano oil/kg diet by the increase in the Lactobacillus spp. frequency and the decrease in intestinal weight in broilers.
\end{abstract}

Key Words: chickens, ileum, microbiota, growth promoter antibiotic, terpenes

\section{ÓLEO ESSENCIAL DE ORÉGANO NA DIETA DE FRANGOS COMO AGENTE ANTIMICROBIANO}

RESUMO: O presente estudo objetivou avaliar a adição de óleo essencial de orégano como agente antimicrobiano e sobre o desempenho de frangos de corte. Utilizou-se 250 pintos de corte, machos, da linhagem Cobb, distribuídos em um delineamento inteiramente casualizado com cinco tratamentos e cinco repetições, com 10 aves cada: dieta com antibiótico e anticoccidiano (controle positivo); dieta sem antibiótico e anticoccidiano (controle negativo); dieta contendo apenas antibiótico; dieta com 0,5g de óleo de orégano; dieta com $1,0 \%$ de óleo de orégano. Foi observada uma menor frequência de bactérias gram-positivas no íleo de frangos de corte tratados sem promotor de crescimento comparado com os grupos controle positivo ou com óleo de orégano $(p<0,01)$. Dentre as bactérias gram-positivas, os Lactobacillus apresentaram uma maior taxa de crescimento no íleo de frangos tratados com promotor de crescimento ou com $1 \mathrm{~g}$ de óleo de orégano/kg de dieta. Porém, nos animais tratados com $0.5 \mathrm{~g}$ de óleo de orégano foi verificada uma menor taxa de crescimento de Lactobacillus comparado com os tratados com $1 \mathrm{~g}$ de óleo de orégano $(p<0,05)$, não diferindo do grupo controle negativo $(p>0,05)$. A adição de $1 \mathrm{~g}$ de óleo de orégano $/ \mathrm{kg}$ de dieta resultou em um menor peso relativo dos intestinos $(p<0.05)$, que não diferiu do grupo controle positivo $(p>0.05)$. Os resultados mostraram que a adição de $1 \mathrm{~g}$ de óleo de orégano/kg de dieta exerceu um efeito antimicrobiano verificado por meio da redução do peso relativo dos intestinos e pelo aumento na frequência de Lactobacillus.

Palavras-chave: aves; íleo; microbiota; antibiótico promotor de crescimento; terpenos 


\section{INTRODUCTION}

In Brazil, at the first quarter of 2011 were slaughtered 8,160 million of pigs and 1,306 billion of chickens (Brasil, 2011). To ensure the productivity and competitiveness of the agribusiness, the use of drugs as growth promoters is a common practice. The infectious diseases that affect the digestive tract of broilers has as one of the main causes economic losses. Faced of this situation, production systems have been based on the control of infectious diseases through the use of growth promoter antibiotics. However, the use of them has been discussed due to the emergence of resistant bacteria. In response to this, for some years it is encouraged the search of alternatives like as essential oils. Plants are a rich source of such compounds with synergistic properties (Gibbons, 2005).

Natural, complex, multi-component essential oils are composed mainly of terpenes such as thymol, cavacrol, citral and others non-terpene components (Edris, 2007). Strong in vitro evidence indicates that essential oils can act as antibacterial agents against a wide spectrum of pathogenic bacterial strains including Listeria monocytogenes, Salmonella typhimurium, Escherichia coli O157:H7, Shigella dysenterica, Bacillus cereus and Staphylococcus aureus (Burt, 2004). The essential oils are designated as generally recognized as safe (GRAS) by the United States, FDA (Godwin and Michniak, 1999; Williams and Barry, 1991). Antimicrobial action of carvacrol and thymol, the main components of oil of oregano has been reported by Burt (2004).

According to Hersch-Martinez, Leaños-Miranda and Solórzano-Santos (2005) the oregano essential oil was effective against gram-negative pathogen. Penalver et al. (2005) verified that the oregano essential oil showed antimicrobial activity with a minimum inhibitory concentration of equal to or less $1 \%$. It has been demonstrated, in vitro, the antimicrobial effect of essential oils but their influence on growth performance of farm animal species has not been sufficiently documented. This study to evaluated the effects of oregano essential oil on performance and antimicrobial activity of broiler chickens.

\section{MATERIAL AND METHODS}

A total 250 day-old male Cobb chicks were housed indoors, on twenty five floor pens, and distributed in a completely randomized design divided into five treatment with five replicates (ten broilers/box) given a basal diet with $10 \mathrm{mg} / \mathrm{kg}$ avilamycin plus $66 \mathrm{mg} / \mathrm{kg}$ salinomycin (positive control); a basal diet without added avilamycin and salinomycin (negative control); basal diet with only added avilamycin at $10 \mathrm{mg} / \mathrm{kg}$ (only antibiotic); basal diet supplemented with $0.5 \mathrm{~g}$ of oregano oil/ $/ \mathrm{kg}$ diet and basal diet with $1.0 \mathrm{~g}$ of oregano oil/kg diet.

The feeding program consisted of a starter diet until $19 \mathrm{~d}$ and a finisher diet until $42 \mathrm{~d}$. The birds were fed a start diet containing $22 \%$ of crude protein and $2900 \mathrm{kcal}$ of metabolizable energy $/ \mathrm{kg}$, and a growing diet with $19 \%$ of crude protein, and $3000 \mathrm{kcal}$ of metabolizable energy $/ \mathrm{kg}$. The basal start diet had $1.5 \%$ of soybean oil and growing diet had $2 \%$ of soybean oil. Oregano oil supplementation was obtained by isometrically replacing soybean oil in the basal diet. Feed and water were supplied ad libitum.

Commercial samples of oregano (Origanum vulgare) of chilean origin were used to obtain the essential oil by hydrodistillation in a modified Clevengertype apparatus, and their analyses were performed by gas-chromatograph with flame ionization detector (GC/FID) according to Cleff et al. (2008).

The feed intake, weight gain and 
feed conversion were calculated. The animals were inspected daily and dead birds were removed following registration of date and body weight. When calculating feed conversion ( $\mathrm{kg}$ $\mathrm{diet} / \mathrm{kg}$ weight), the body weights of dead animals were also considered.

Five birds per treatment were sacrificed by cervical dislocation; the small intestine was rapidly excised at Meckel's diverticulum to the ileocecal junction; the ileum were removed aseptically, clamped with forceps, and placed in sterile plastic bags on ice. In the laboratory, the narrow open ends of the ileum were cut with sterile scissors. Approximately $100 \mathrm{mg}$ of ileal content was collected into an eppendorff tube containing about of $1 \mathrm{~mL}$ of of sterile reduced sodium thioglycollate broth, and homogenized by mild agitation for three seconds. The samples were submitted to a serial decimal dilution in sterile reduced sodium thioglycollate broth up to $10^{-6}$. However only $10^{-6}$ dilution were considered for bacterial CFU counts with $0.1 \mathrm{~mL}$ was plated into culture media for the identification of bacteria. All culture media - Mueller-Hinton blood agar, Man Rogosa Sharp (MRS) agar, Azide blood agar, MacConkey agar - were incubated in an anaerobic cabinet (GasPak, BBL) at $37^{\circ} \mathrm{C}$ for $48 \mathrm{~h}$.

The Lactobacillus spp. count was determined presumptively using MRS agar (BBL. Beckton Dickinson, USA). From azide blood agar plates showing pure growth, two typical colonies were subcultured for separation between Enterococcus and Streptococcus species, by verifying the ability for enzymatically hydrolase a I-pyrrolidonylbeta-naphthalamide substrate as well as positive for esculin hydrolysis and positive growth with 6.5\% (wt/vol) sodium chloride brain heart infusion broth at $45^{\circ} \mathrm{C}$. Also, each colony presenting distinct morphology was isolated, stained by Gram and tested for catalasys. Others enterobacteria were enumerated on MacConkey agar after anaerobic incubation at $37^{\circ} \mathrm{C}$ for $48 \mathrm{~h}$. Besides, the relative intestine weight was determined (small intestine and ceca) at 19 and 42 days of age.

The experimental data was subject to an analysis of variance using the System for Statistical and Genetic Analyses, developed by UFV (1997). Significant differences among means were determined by Student NewmanKeul's (SNK) test at $p \leq 0.05$ throughout these studies. Microbiology parameters were compared using the Fisher test at a probability of $5 \%(p \leq 0.05)$.

\section{RESULTS AND DISCUSSION}

Investigations concerning to the growth performance and antimicrobial activity of the essential oils of the plant have been conducted in the search for new compounds to replace synthetic ones. In our results, the extraction yield of the oregano essential oil was determined to be $1.20 \mathrm{wt} \% \pm 0.18 \mathrm{wt} \%$, achieved after about $3 \mathrm{~h}$ of extraction. The chromatogram of oregano essential oil shows that 4-terpinenol, $\gamma$-terpinene and thymol are the major components, followed by $\alpha$-terpinene, $p$-cymene and $\alpha$-terpineol, which means a chemical profile very similar to that found by Rodrigues (2002).

It was shown in this study that $O$. vulgare L. had a high percentage of thymol compared to carvacrol. With respect to the terpene compounds, several researches have indicated higher inhibition of microorganisms by thymol followed by carvacrol (Lattaoui and Tantaoui-Elaraki, 1994).

There was no effect of treatments on body weight gain $(p>0.05)$. Similar results were observed by Rizzo et al. (2010) that reported no differences in final body weight among chickens fed oregano. According Traesel et al. (2011), essential oil of oregano, in highest dose, exerts less stimulating 
humoral immune system of broilers, as with the supplementation of growthpromoting antibiotics.

It was observed that the positive control group had the highest feed intake ( $p \leq 0.05)$ whereas that the broilers fed with $1 \mathrm{~g}$ of oregano oil $/ \mathrm{kg}$ diet had better fed conversion at 1-19 days of age without to influence negatively feed consumption (Table 1 ).

Table 1. Growth performance of broilers chickens

\begin{tabular}{|c|c|c|c|}
\hline \multirow[t]{2}{*}{ Diet } & 1-19 days & $20-42$ days & $1-42$ days \\
\hline & \multicolumn{3}{|c|}{ Body weight gain ( $\mathrm{g} / \mathrm{bir}$ ) } \\
\hline Positive control ${ }^{1}$ & 412.21 & 1451.21 & 1870.43 \\
\hline Negative control $^{2}$ & 376.45 & 1498.06 & 1880.36 \\
\hline Only antibiotic ${ }^{5}$ & 392.18 & 1551.38 & 1948.02 \\
\hline $\begin{array}{l}0.5 \mathrm{~g} \text { of oregano } \\
\text { oil } / \mathrm{kg}\end{array}$ & 370.05 & 1412.01 & 1787.66 \\
\hline \multirow[t]{2}{*}{$\begin{array}{l}1.0 \mathrm{~g} \text { of oregano } \\
\text { oil } / \mathrm{kg}\end{array}$} & 429.42 & 1485.95 & 1925.75 \\
\hline & \multicolumn{3}{|c|}{ Feed intake $(\mathrm{g} / \mathrm{bird})$} \\
\hline Positive control ${ }^{1}$ & $740.16 \mathrm{~A}$ & 2962.05 & 3702.22 \\
\hline Negative control $^{2}$ & $665.48 \mathrm{AB}$ & 2932.30 & 3597.78 \\
\hline Only antibiotic ${ }^{5}$ & 693.12AB & 3084.17 & 3747.29 \\
\hline $\begin{array}{l}0.5 \mathrm{~g} \text { of oregano } \\
\mathrm{oil} / \mathrm{kg}\end{array}$ & $627.08 \mathrm{~B}$ & 2871.37 & 3498.45 \\
\hline \multirow[t]{2}{*}{$\begin{array}{l}1.0 \mathrm{~g} \text { of oregano } \\
\text { oil } / \mathrm{kg}\end{array}$} & $697.36 \mathrm{AB}$ & 3090.00 & 3787.36 \\
\hline & \multicolumn{3}{|c|}{ Feed conversion (feed gain ratio) } \\
\hline Positive control $^{\top}$ & $1.79 \mathrm{~A}$ & 2.04 & 1.98 \\
\hline Negative control ${ }^{2}$ & $1.76 \mathrm{~A}$ & 1.95 & 1.91 \\
\hline Only antibiotic ${ }^{3}$ & $1.77 \mathrm{~A}$ & 1.98 & 1.92 \\
\hline $\begin{array}{l}0.5 \mathrm{~g} \text { of oregano } \\
\mathrm{oil} / \mathrm{kg}\end{array}$ & $1.69 \mathrm{AB}$ & 2.03 & 1.95 \\
\hline $\begin{array}{l}1.0 \mathrm{~g} \text { of oregano } \\
\text { oil } / \mathrm{kg}\end{array}$ & $1.62 \mathrm{~B}$ & 2.08 & 1.96 \\
\hline \multicolumn{4}{|c|}{$\begin{array}{l}\text { A, } 8 \text { Averages values within the same column with no common superscript } \\
\text { differ significantly by the SNK test }(p<0.05) \text {. } \\
{ }^{1} \text { diet with antibiotic and anticoccidial - } 10 \mathrm{mg} / \mathrm{kg} \text { avilamycin plus } 66 \mathrm{mg} / \mathrm{kg} \\
\text { salinomycin } \\
2 \text { diet without antibiotic and anticoccidial } \\
310 \mathrm{mg} / \mathrm{kg} \text { avilamycin }\end{array}$} \\
\hline
\end{tabular}

It was focused on the ileal microbiota of broilers because previous studies showed that this population of microorganisms is similiar to the jejunum (Van Der Wielen et al., 2002). According to Lu et al. (2003) in the ileum of broilers chickens, Lactobacillus species accounted for $67 \%$ of the total, with the majority of the rest being related to Clostridiaceae (11\%), Streptococcus (6.5\%) and Enterococcus (6.5\%), totaling $91 \%$ of gram-positive bacteria. Our results of microbiology assay showed that the broilers chickens fed with growth promoter or $1 \mathrm{~g}$ of oregano oil $/ \mathrm{kg}$ have a predominance of grampositive bacteria in the ileum. Fisher's exact test for occurrence frequency from gram-positive bacteria showed significantly lower frequency in the ileum of negative control group compared to chickens treated with growth promoter antibiotic or supplemented with oregano oil $(p \leq 0.01)$ displayed in Figure 1 and Table 2.

Table 2. Comparison between the frequencies of gram-positive bacteria Lactobacillus spp. and Enterococcus by Fischer exact test for groups of two treatments, for a total of fourth treatments

\begin{tabular}{|c|c|c|c|c|}
\hline \multirow[b]{2}{*}{ Treatments } & \multicolumn{4}{|c|}{ Gram-positive bacteria } \\
\hline & $\begin{array}{l}\text { Negative } \\
\text { control }\end{array}$ & $\begin{array}{l}\text { Only } \\
\text { antibiotic }\end{array}$ & $\begin{array}{l}0.5 \mathrm{~g} \text { of } \\
\text { oregano oil } / \mathrm{kg}\end{array}$ & $\begin{array}{l}1.0 \mathrm{~g} \text { of oregano } \\
\text { oil } / \mathrm{kg}\end{array}$ \\
\hline $\begin{array}{l}\text { Positive control } \\
\text { Negative control }\end{array}$ & ** & n.S. & n.S. & n.s. \\
\hline $\begin{array}{l}\text { Only antibiotic } \\
0.5 \mathrm{~g} \text { of oregano } \\
\text { oil/kg }\end{array}$ & & & n.s. & $\begin{array}{l}\text { n.s. } \\
\text { n.s. }\end{array}$ \\
\hline \multirow{5}{*}{$\begin{array}{l}\text { Positive control } \\
\text { Negative control } \\
\text { Only antibiotic } \\
0.5 \mathrm{~g} \text { of oregano } \\
\text { oil/kg }\end{array}$} & \multicolumn{4}{|c|}{ Lactobacillus spp } \\
\hline & ** & n.s. & n.s. & n.s. \\
\hline & & ** & n.s & \\
\hline & & & & n.s. \\
\hline & & & & ** \\
\hline \multirow{5}{*}{$\begin{array}{l}\text { Positive control } \\
\text { Negative control } \\
\text { Only antibiotic } \\
0.5 \mathrm{~g} \text { of oregano } \\
\text { oil/kg }\end{array}$} & \multicolumn{4}{|c|}{ Enterococcus spp } \\
\hline & $\pi \star$ & n.s. & n.s. & n.s. \\
\hline & & ** & n.s & n.s \\
\hline & & & n.s. & n.s. \\
\hline & & & & n.s. \\
\hline $\begin{array}{l}\text { n.s. = the frequency } \\
\text { probability by the test } \\
\star \star= \\
=\text { the frequency of tr }\end{array}$ & $\begin{array}{l}\text { of treatm } \\
\text { of Fischer } \\
\text { eatments }\end{array}$ & & & $\begin{array}{l}\text { at } 5 \% \text { level of } \\
\text { of } 1 \% \text { probability }\end{array}$ \\
\hline
\end{tabular}

Besides, the negative control group had also lower growth for Lactobacillus spp. and higher for Enterococcus spp. compared with positive control group (Table 2). Lactobacillus spp. had higher growth in the positive control group or supplemented with $1 \mathrm{~g}$ of oregano oil/kg diet ( $p \leq 0.05$, Table 2). However, the frequency of Lactobacillus spp in chickens supplemented with $0.5 \mathrm{~g}$ of oregano oil/kg diet was lower than of those_supplemented with $1 \mathrm{~g}$ of oregano oil/kg diet as well as did not differ from negative control group ( $p \leq 0.05$, Table 2).

Our results corroborate Collier et al. (2003) that using tylosin, active against gram positives as well avylamicin, observed increase in lactobacilli. Regarding the action of plant extracts on the microbial growth, Friedman, Henika and Mandrell (2002) verified that the oregano essential oil was active against gram-negative bacteria. This effect was also observed in our results shown in Figure 1. 


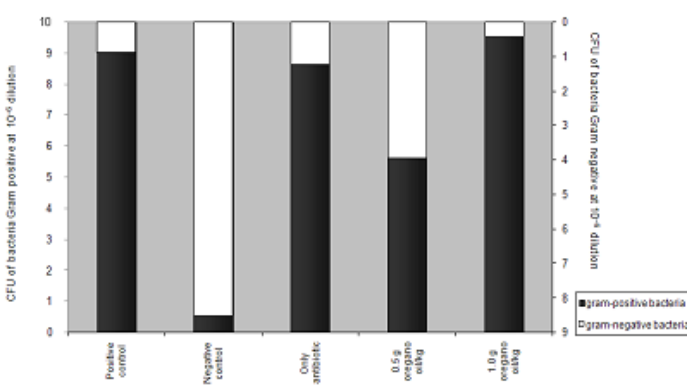

Figure1. - Colony-forming unit (CFU) of bacteria Gram positive and Gram negative lleum of broilers at 42 days old - dilutions $10^{-6}$ media agar blood sodium azide / M acConkey agar.

Bona et al. (2012) evaluated the efficiency of a product in broiler feed containing essential oil of oregano, rosemary, cinnamon and extract of red pepper (plant compost) in the control of Salmonella, Eimeria and Clostridium. These authors observed that the use of the plant compost in broiler diets reduced specific lesions of $E$. maxima and E. tenella at 14 days after inoculation and reduced the count of colony forming units of Clostridium perfringens in the ceca comparing to the control group. Also, it was verified that the use of the plant compost and avilamycin decreased the excretion of Salmonella in poultry 72 hours after the inoculation. Fukayama et al. (2005) evaluated the the efficacy of oregan extract levels $(0.025 \%, 0.050 \%, 0.075 \%$, $0.100 \%$ ) in the broilers diets and it was observed a decrease on the number of bacteriums in caecum as the dietary level of oregan extract increased showed the antimicrobian effect of oregan extract.

Therefore in our research it was verified that the use of oregano oil at $1 \mathrm{~g} / \mathrm{kg}$ diet promoted an inhibited the growth of gram negative bacteria that probably contributed to an enhancing in frequency of Lactobacillus. There are no studies on the action of oil of oregano on the frequency of lactobacillus in the ileum of broiler chickens.

In the present investigation, it was observed only in ileum from negative control group at $10^{-6}$ dilution, the presence of endospore-forming grampositive rods hemolitic which suggested Clostridium spp. Therefore the diets with growth promoter antibiotic or supplemented with oregano oil, in both concentrations, had inhibitory effect on the growth of anaerobe endosporeforming gram-positive rods do tipo Clostridium spp.

There was not significant changes in the other population of bacteria $(p>$ $0.05)$. Avilamycin is an antibiotic which acts mainly on Clostridium spp., Staphylococcus aureus, Streptococcus spp. which therefore confirm our results. The mean values of intestine relative weight are presented in Table 3 .

Table 3. Relative intestine weight of broilers fed with growth promoter antibiotic or oregano oil

\begin{tabular}{lcc}
\hline Diet & \multicolumn{2}{c}{ Intestine $(\mathrm{g} / 100 \mathrm{~g}$ of live weight) } \\
\hline & 19 days of age & 42 days of age \\
\cline { 2 - 3 } Positive control & $12.11 \mathrm{AB}$ & 5.18 \\
Negative control & $13.16 \mathrm{~A}$ & 6.52 \\
Only antibiotic & $13.32 \mathrm{~A}$ & 5.63 \\
$0.5 \mathrm{~g}$ of oregano oil $/ \mathrm{kg}$ & $12.74 \mathrm{~A}$ & 6.53 \\
$1.0 \mathrm{~g}$ of oregano oil/kg & $10.34 \mathrm{~B}$ & 6.48 \\
\hline $\mathrm{A}, \mathrm{B}$ Averages values within the same column with no common superscript \\
differ significantly by the SNK test $(\mathrm{p}<0.06)$.
\end{tabular}

At 19 days of age, it was observed that the use of $1.0 \mathrm{~g}$ of oregano oil $/ \mathrm{kg}$ diet had the lowest relative intestine weight which did not differ significantly from positive control group ( $p \leq 0.05)$. However, there was no effect of treatments on intestine relative weight at 42 days of age $(p>0.05)$. The decrease in intestinal weight in broiler chicks denotes a lower thickness that resulted in a better feed conversion rate during 119 days of age (Table 2 ).

Thus, it has shown some effects from oregano oil on gut microbiota populations. It has been hypothesized that gut microflora decrease nutrient absorption by increasing gastrointestinal tract thickness by Apajalahti et al. (2004). This effect was observed in our results in animals with 19 days of age. In the studies conducted by Silva et al. (2009) it was verified that he broilers fed with positive control (antibiotic and anticoccidial) had the highest villous: 
crypt ratio compared with the negative control that had the lowest villous:crypt ratio and the highest oocyst excretion in litter $(p<0.05)$. Also, it was observed that broilers fed with non anticoccidial agent had the highest cecal lamina propria thickeness which differ from chickens fed with anticoccidial agent in diet or supplemented with 1.0 of oregano oil kg diet-1 ( $p<0.05)$.

\section{CONCLUSION}

The results showed that the dietary oregano oil exerted growth-promoting effect on broilers at $1.0 \mathrm{~g}$ of oregano oil/kg diet by an inhibited the growth of gram negative bacteria that probably contributed to an enhancing in frequency of Lactobacillus spp. and an decrease in the intestinal weight in broiler chicks at 19 days of age.

Therefore, the oregano essential oil can be used as an alternative to growth promoters in animal diet.

\section{ACKNOWLEDGMENTS}

The authors are grateful to the Banco do Nordeste do Brasil (BNB, 6657), Fundação de Apoio à Ciência e Tecnologia do Espirito Santo (FAPES, 31180353/2005) and CNPq for financial support.

\section{INFORMATIVE NOTES}

The protocol of animal experimentation is in accordance to CONCEA and was approved by the Ethics Committee in Use of Animals of Espirito Santo Federal Univesity from Protocol No. 01/08.

\section{REFERENCES}

APAJALAHTI, J. Characteristics of the gastrointestinal microbial communities, with special reference to the chicken. World's Poultry Science Journal, v.60, n.2, p 223-232, 2004.
BAMPIDIS, V. A.; CHRISTODOULOU, V.; FLOROU-PANERI, P. et al. Effect of dietary dried oregano leaves on growth performance, carcase characteristics and serum cholesterol of female early maturing turkeys. British Poultry Science, v.46, n.5, p.595-601, 2005.

BONA, T. D. M. M.; PICKLER, L.; MIGLINO, L. B. et al. Óleo essencial de oregano, alecrim, canela e extrato de pimenta no controle de Salmonella, Eimeria e Clostridium em frangos de corte. Pesquisa Veterinária Brasileira, v.32, n.5, p.411-418, 2012.

BRASIL. Ministério do Planejamento, Orçamento e Gestão. Instituto Brasileiro de Geografia e Estatística. Disponível em:

<http://www.brasil.gov.br/noticias/arquivos/2011/ 06/30/no-1o-trimestre-de-2011-abate-de-frangocresce-8-2-em-relacao-ao-mesmo-periodo-de2010/print>. Acesso em: Janeiro 2013.

BURT, S. Essential oils: their antibacterial properties and potential applications in foods - a review. International Journal of Food

Microbiology, v.94, n.3, p.223-253, 2004.

CLEFF, M. B. MEINERZ, A. R. M.; SCHUCH, L. F. D. et al. Atividade in vitro do óleo essencial de Origanum vulgare frente à Sporothrix Schenckii. Arquivo Brasileiro de Medicina Veterinária e Zootecnia, v.60, n.2, p.513-516, 2008.

COLLIER, C. T.; SMIRICKY-TJARDES, M. R.; ALBIN, D. M. et al. Molecular ecological analysis of porcine ileal microbiota responses to antimicrobial growth promoters. Journal of Animal Science, v.81, n.12, p.3035-3045, 2003.

EDRIS, A. E. Pharmaceutical and therapeutic potentials of essential oils and their individual volatile constituents: A review. Phytotherapy Research, v.21, n.4, p.308-23, 2007.

FRIEDMAN, M.; HENIKA, P. R.; MANDRELL, R. E. Bactericidal activities of plant essential oils and some of their isolated constituents against Campylobacter jejuni, Escherichia coli, Listeria monocytogenes, and Salmonella enterica. Journal of Food Protection, v.65, n.10, p.15451560, 2002.

FUKAYAMA, E. H.; BERTECHINI, A. G.; GERALDO, A. et al. Extrato de orégano como aditivo em rações para frangos de corte.

Revista Brasileira de Zootecnia, v.34, n.6, p.2316-2326, 2005.

GIBBONS, S. Plants as a source of bacterial resistance modulators and anti-infective agents. Phytochemistry Reviews, v.4, n.1, p.63-78, 2005. 
GODWIN, D. A.; MICHNIAK, B. B. Influence of drug lipophilicity terpenes as transdermal penetration enhancers. Drug Development and Industrial Pharmacy. v.25, n.8, p.905-915, 1999.

HERSCH-MARTINEZ, P.; LEAÑOS-MIRANDA, B. E.; SOLÓRZANO-SANTOS, F. Antibacterial effects of commercial essential oils over locally prevalent pathogenic strains in Mexico.

Fitoterapia, v.76, n.5, p.453-457, 2005.

KNARREBORG, A.; SIMON, M. A.; ENGBERG, R. M. et al. Effects of dietary fat source and subtherapeutic levels of antibiotic on the bacterial community in the ileum of broiler chickens at various ages. Applied and Environmental Microbiology, v.68, n.12, p.5918-5924, 2002.

KNOBLOCH, K.; SIMON, M. A.; ENGBERG, R. $M$. et al. Progress in Essential Oil Research. Berlin. Walter de Gruyther.1986. 429 p.

LATTAOUI, N.; TANTAOUI-ELARAKI, A. Individual and combined antibacterial activity of the main constituents of the three essential oils. EPPOS, v.3, n.1, p.13-19, 1994.

LU, J.; IDRIS, U.; HARMON, B.; HOFACRE, C. et al. Diversity and succession of the intestinal bacterial community of the maturing broiler chicken. Applied and Environmental Microbiology, v.69, n.11, p.6816-6824, 2003.

PENALVER, P.; HUERTA, B.; BORGE, C. et al. Antimicrobial activity of five essential oils against origin strains of the Enterobacteriaceae family.

Acta Pathologica, Microbiologica et

Immunologica Scandinavica, v.113, n.1, p.1-6, 2005.

RODRIGUES, M. R. A. Estudos dos óleos essenciais presentes em manjerona e orégano. 2002. Pp.148. Thesis D.Sc. Instituto de Química. Universidade Federal do Rio Grande do Sul. Porto Alegre, RS.

RIZZO, P. V.; MENTEN, J. F. M.; RACANICCI, A. M. C. et al. Extratos vegetais em dietas para frangos de corte. Revista Brasileira de Zootecnia, v.39, n.4, p.801-807, 2010.

SILVA, M. A.; PESSOTTI, B. M. S.; ZANINI, S. F.; et al. Intestinal mucosa structure of broiler chickens infected experimentally with Eimeria tenella and treated with essential oil of oregano. Ciência. Rural, v.39, n.5, p.1471-1477, 2009.

TRAESEL, K.C.; LOPES, S.T. A.; WOLKMER, $P$. et al. Óleos essenciais como substituintes de antibióticos promotores de crescimento em frangos de corte: perfil de soroproteínas e peroxidação lipídica. Ciência Rural, v.41, n.2, p.278-284, 2011.
UNIVERSIDADE FEDERAL DE VIÇOSA - UFV, (1997). Manual de utilização do programa SAEG (Sistema para Análise Estatística e Genéticas). Viçosa: UFV. 150p.

VAN DER WIELEN, P. W. J. J.; KEUZENKAMP, D. A.; LIPMAN, L. J. et al. Spatial and temporal variation of the intestinal bacterial community in commercially raised broiler chickens during growth. Microbial Ecology. v.44, n.3, p.286293, 2002.

WILLIAMS, A. C.; BARRY, B. W. Terpenes and the lipid-protein- partitioning theory of skin penetration enhancement. Pharmaceutical Research, v.8, n.1, p.17-24, 1991. 